\title{
Analysis on the Development of Jiangxi Leisure Fishery
}

\author{
Yan Peng ${ }^{1}$, Hui Wang ${ }^{2}$ \\ ${ }^{1}$ Jiangxi science and technology Normal University, Nan Chang, Jiang Xi, 330038 \\ ${ }^{2}$ Jiangxi Institute of Applied Science and technology, Nan Chang, Jiang Xi, 330038
}

Jiangxi Department of Education, Science and Technology Project "The Study of Jiangxi Urban

Sustainable Tourism Development Mode"

Project NO. GJJ13558

93762541@163.com

Keywords: Jiang Xi; Leisure Fishery; Overview

\begin{abstract}
Jiangxi is rich in water resources. But its leisure fishery is overall in the initial stage of development and shows low Comprehensive index of economic development and large region development differences. Therefore, based on the investigating in present development situation of Jiangxi leisure fishery this paper takes eight comprehensive index to empirically analyze the development level of ten key fishery counties around Poyang Lake which reflects the economic development level of leisure fishery. The aim is to reveal the main product system and the existing problems in the development of leisure fishery in Jiangxi province and put forward effective measures to promote the rapid development of it.
\end{abstract}

\section{Introduction}

The term leisure fishery is first appeared in the last 1960s and used in the domestic around 1980s. Taiwan scholars believe that recreational fishing is the integrated using of the fishing village equipment, fishing village space, fisheries production sites, fishing gear method, fishery products, fishing operations, natural biological, natural environment of the fisheries and the cultural resources of the fishing village, through planning and designing, in order to play the function of fisheries and fishing villages on leisure travel. Leisure fishery enhances people's experience in fishing villages and fishery, improves the quality of tourism, increase the revenue of fishermen and promote the development of the fishery village ${ }^{[1]}$. Compared to other studies, leisure fishery research is still in its infancy. The existing domestic research focused primarily on basic theoretical research of recreational fishing and leisure supply study. The study area is mainly concentrated in Guangdong, Fujian, Hainan, Zhejiang, Shanghai and other coastal areas. The relevant Jiangxi leisure fishery research is rare. Studies have shown that the pace of development in Jiangxi leisure fishery is relatively fast. Especially the leisure fishery in the Poyang Lake area tourism industry in southern Jiangxi province has a unique advantage because of water resource advantages of Poyang Lake which is largest freshwater lake in China. It has played a greater role in providing entrepreneurial opportunities and increasing the income of fishermen. This paper takes comprehensive index method to analysis the level of economic development of Jiangxi leisure fishery based on the data of leisure fishery from the 10 key lake fishery counties. Based on the results of previous studies, we make a further analysis of the influence factors of the economic development on Jiangxi leisure fishery in order to provide effective measures for the development of it ${ }^{[2]}$.

\section{Research Methods}

In this paper, an integrated index, 10 counties around Poyang Lake in Jiangxi have been taken for the study, on the level of economic development of leisure fishery for evaluation, in order to promote the development of Jiangxi leisure fishery. Composite index method is the same or 
different index values set by statistical analysis, so that the different units of measurement, standardization index value nature, and finally transformed into a composite index to accurately evaluate the comprehensive level of work. The larger the index value, the better the quality of work, the number of indicators is not limited. Formula is as follows ${ }^{[3]}$ :

$$
F(x)=\sum_{i=1}^{m} \lambda_{i} x_{i}
$$

$F(x)$ is the economic development of a comprehensive evaluation function. $\lambda_{i}$ The value is set to 1 the sum

\section{Establish a Data Source and Evaluation System}

The Original Data Collection and Index Selection. In this paper, all of the data is from the Jiangxi Provincial Fishery Bureau, Jiangxi Province in 2014 Fishery Bureau on the development of the province's leisure fishery survey statistics, data from the 100 counties reporting fishery sector, and then by the 11 municipalities and districts of fisheries and fisheries statistical summary report from the government sector. For a small amount of missing data, based on annual average growth rates and expert law be calculated after the assignment ${ }^{[4]}$.

In this paper, leisure fishery economic development in Jiangxi set the total evaluation function $F(x)$. The value $\lambda_{i}$ is set to 1 the sum. To avoid subjective sources of error, so the index weight more objective, credible, each index weight using entropy weighting method calculated (Table 1).

Table 1 Jiangxi leisure fishery economic development index system and comprehensive evaluation of heavy weight

\begin{tabular}{|l|l|l|l|}
\hline Leisure & Evaluation items & Indicator & Weights \\
Vystem & Falue Unit & \\
\hline $\begin{array}{l}\text { Tourism } \\
\text { Industry } \\
\text { System }\end{array}$ & Fishery total value $x_{1}$ & 10 K yuan & 0.1995 \\
\cline { 2 - 4 } & Leisure fishery Base $x_{2}$ & family & 0.1248 \\
\cline { 2 - 4 } & Leisure fishery Area $x_{3}$ & Mu & 0.1926 \\
\cline { 2 - 4 } & Base Total investment ${ }^{x_{4}}$ & 10 K yuan & 0.1104 \\
\cline { 2 - 4 } & Practitioners $x_{5}$ & person & 0.0754 \\
\cline { 2 - 4 } & Ability tourists $x_{6}$ & Person*times & 0.1163 \\
\cline { 2 - 4 } & Leisure fishery income $x_{7}$ & 10 K yuan & 0.1305 \\
\cline { 2 - 4 } & Total revenue base ${ }^{x_{8}}$ & 10 K yuan & 0.0505 \\
\hline
\end{tabular}

Standardization Process Raw Data. Let $x_{1}, x_{2}, x_{3}, \ldots ., x_{8}$ is Jiangxi leisure fishery development system orderly features of the order parameter index (Table 1), to eliminate the influence of the index unit for the calculation results, dimensionless process indicators. Because of the various indicators of this article are of an orderly system features positive indicators, so the use of processing methods see the following formula ${ }^{[5]}$.

$$
\begin{aligned}
& x_{i}=\left[x_{i}-\min \left(x_{i}\right)\right] /\left[\max \left(x_{i}\right)-\min \left(x_{i}\right)\right] \\
& x_{i}=\left[\max \left(x_{i}\right)-x_{i}\right] /\left[\max \left(x_{i}\right)-\min \left(x_{i}\right)\right]
\end{aligned}
$$




\section{The Comprehensive Evaluation Index Analysis of 10 Counties in Jiangxi Leisure Fishery Development}

Table 2 Jiangxi level development of an integrated value of leisure fishery

\begin{tabular}{|c|c|c|c|c|c|}
\hline Area & $\begin{array}{c}\text { Nanchang } \\
\text { County }\end{array}$ & $\begin{array}{c}\text { Jingxian } \\
\text { County }\end{array}$ & $\begin{array}{c}\text { Xinjian } \\
\text { County }\end{array}$ & $\begin{array}{c}\text { Lushan } \\
\text { County }\end{array}$ & $\begin{array}{c}\text { Xingzi } \\
\text { County }\end{array}$ \\
\hline$F(x)$ & 0.5822 & 0.2888 & 0.0843 & 0.3379 & 0.0285 \\
\hline Area & $\begin{array}{c}\text { Yongxiu } \\
\text { County }\end{array}$ & $\begin{array}{c}\text { Douchang } \\
\text { County }\end{array}$ & $\begin{array}{c}\text { Yugan } \\
\text { County }\end{array}$ & $\begin{array}{c}\text { Boyang } \\
\text { County }\end{array}$ & $\begin{array}{c}\text { Wannian } \\
\text { County }\end{array}$ \\
\hline$F(x)$ & 0.2105 & 0.0718 & 0.2835 & 0.5479 & 0.1813 \\
\hline
\end{tabular}

The level of development of strong regional leisure fishery: Nanchang County, Poyang County, the integrated value $F(x) \geq 0.5$. The level of development of leisure fishery in general areas: Lushan District, Yugan, Jinxian, Yongxiu County, Wannian County, its comprehensive value $0.1 \leq F(x) \leq 0.5$.

From comprehensive view, comprehensive evaluation index value of Jiangxi counties leisure fishery development is low, the highest level of development of Nanchang County, scores 0.5822, the lowest Xingzi County, scores 0.0285. Quite different counties about the overall trend of an uneven development potential has been tapped.

\section{The Strategies to Enhance Jiangxi Leisure Fishery Development Level}

To avoid duplication of low-level development of leisure fishery, experts should be commissioned by the provincial tourism and fisheries sectors or hire a third party prepared Jiangxi leisure fishery overall development plan, change the current status of small scattered as soon as possible, built more than leisure, vacation, travel, sightseeing and entertainment in an integrated package type leisure fishery base. Abundant leisure fishery products, recreational fishing, based on the focus on waterfront restaurant, sand sculpture, characteristic fishing village, fishing fun, fishing, hunting and camping products to build experience. In addition, the need to develop recreational fishing area, service stars, base construction, health and safety and other aspects of the industry standard for the leisure fishery in Jiangxi raise the overall level of development.

In 2015, the State Council issued "make highly entrepreneurial innovation to vigorously promote the public a number of policies and measures opinions", clearly states that "continuously improve the institutional mechanisms, improve inclusive policy measures to strengthen co-ordination, the building is conducive public business, Peoples innovation to flourish policy environment, institutional environment and public service system, in order to promote employment, entrepreneurship, innovation and development. "Recreational fisheries", while having some of the characteristics of the tertiary industry, but still closely linked with the large agriculture should develop appropriate policies to promote the industries continue to grow. First, the capital, to strengthen the coordination and contact financial institutions and development projects to attract more and more favorable financial support. The Government should also allocate special funds same level of financial subsidies and interest payments on loans for investment emphasis recreational fisheries projects. Second, the land, we need to establish and improve the rural land transfer system, regulate land paid transfer as soon as possible. License within the scope of the policy, to a small part of the nature of changes in land use, agricultural activities still as the main recreational fisheries projects, provision of agricultural land should be the implementation of internal restructuring. Third, the tax aspect, water and electricity supply to the recreational fishery projects, agriculture and hydropower pricing policy should be implemented. Pricing and management of leisure agricultural projects should be given some preferential policies, both the broad consumer acceptance, but also make the project itself obtain certain economic benefits. 
Government and industry management department on the one hand and vigorously support the development of recreational fisheries, and the need to regulate market behavior related to recreational fisheries. Especially to strengthen the guidance and management in consumer prices, service facilities, emergency treatment, security management, food hygiene, personal safety, etc., to create a good environment for the sustained and stable development of the Jiangxi recreational fisheries. But also to strengthen the training of practitioners related management, service concept, brand marketing knowledge, and continuously improve the quality of recreational fisheries practitioners and management capabilities.

Poyang Lake waters, resources, and cultural factors are unmatched in other lakes, but the visibility of their recreational fisheries even as Qiandao Lake in Zhejiang. Therefore, the government and industry management and practitioners must work hard to build the brand, strengthen the overall packaging publicity and so on. First, through a variety of media, using a variety of ways, inside and outside the tourist-oriented province, widely publicized Jiangxi fishing culture, improve visibility. The second is to further close the recreational fishery and tourism organically integrated, increased water tourism, water ornamental fish and set fishing, catch, fresh goods as one of the tourism project. Third, the development of ornamental fisheries, expand the connotation of recreational fisheries, such as the rich resources of Poyang Lake finless porpoise Yugan, Chang and other waters, you can develop other leisure activities.

\section{Conclusion}

The prospects of leisure fishery in Jiangxi are very bright. Because it can realize integrated using of the fishery resources and play an important part in deepening agricultural structure and enriching tourism industry in the Poyang Lake area. Jiangxi leisure fishery is currently in the early stages of development. So its development should adhere to market-oriented to improve the economic benefits, social and ecological benefits of fisheries. At the same time its development should follow the principle of "scientific planning, maintain the characteristics, protect resources and sustainable development" and give full play to natural resources and cultural resources advantage of local. We should establish the leisure fishery projects which can adapt to different levels and types consumers and finally found brand characteristics of Jiangxi leisure fishery.

\section{References}

[1] Cai-Shou, S. Theory and Practice of Development of Leisure Fishery. Qingdao: China Ocean University .2009.

[2] Dong-Fu L. The Study on Suburban Leisure Fishery Development. Jilin Agricultural, 2013,01 (299): 6.

[3] Xu Y. Contention Leisure Fishery Development Model and Countermeasures-A Case Study in Zhoushan. Zhejiang Ocean University, 2012.

[4] Fan M. China Taiwan Leisure Fishery Research and Development Experience. World Agriculture, 2013,9 (413): 162--166.

[5] Chen-Lan S. Leisure Fishery to Promote New Rural Construction. Chinese Fisheries, 2010(11): 12-17. 